\title{
Evaluation the role of Apsa-mos® as immunomodulator on the level of antibody titers in broiler chickens vaccinated with Newcastle disease virus
}

\author{
Th.Y. Al-Hbiti ${ }^{\circledR}$ and Z.A. Al-Noaimy \\ Department of Pathology and Poultry Diseases, College of Veterinary Medicine, University of Mosul, Mosul, Iraq
}

\section{Article information \\ Article history: \\ Received November 19, 2020 \\ Accepted April 16, 2021 \\ Available online November 15, 2021}

\section{Keywords:}

Newcastle disease

Vaccine

Immunity

Apsa-mos $^{\circledR}$

Histopathology

\section{Correspondence:}

Th.Y. Al-Hbiti

thanoon_th@uomosul.edu.iq

\begin{abstract}
The aim of our study is to evaluate the effect of Apsa-mos ${ }^{\circledR}$ as immunostimulant on the level of antibodies in broiler chickens vaccinated with Newcastle disease live attenuated vaccine ( $\beta 1$ and lasota strain) at 10, 24-day old respectively. Forty, one-day-old chicks were reared in this experiment. They were divide into four groups and treated as follows: Chicks in the 1st group were treated as control one (G1); Chicks in the group 2 (G2), were vaccinated with live attenuated $\beta 1 \mathrm{NDV}$ vaccine at 10 days followed by attenuated lasota NDV strain vaccine at 24 days of age, chicks in the group three (G3) were vaccinated as in group 2 but amended with Apsa-mos ${ }^{\circledR}$ at a rate of $1 \mathrm{mg} / \mathrm{kg}$ of feed; Chicks in the 4th treatment was given Apsa-mos ${ }^{\circledR}$ only at a rate of $1 \mathrm{mg} / \mathrm{kg}$ of feed. Antibody titers after administration of NDV vaccines were estimated using ELISA technique. The results showed a significant difference in the titers between the vaccinated and non-vaccinated birds with higher values when Apsa- mose ${ }^{\circledR}$ was added, in comparison with groups 1 and 4. No significant changes were noticed between granulocytes differential counts and in the values of stress factor of heterophiles/lymphocytes (H/L ratio) in all treated groups. Amending Apsa-mos ${ }^{\circledR}$ to the feeds of the treated birds G3 and G4 has no negative effect on the treated and play a positive role by restoring the normal architecture of lymphoid tissues of bursa of Fabrecious and caecal tonsils. We concluded that the giving of Apsa-mos improve the immune state of the chicks in both types humeral and cellular immunity especially in G3 and decreased the influence of the vaccine in this group and increase the immunity in G4 also Apsa-mos decrease the effect of the vaccine in G3 seen in histological changes in bursa of fabricious and cecal tonsils.
\end{abstract}

DOI: $10.33899 /$ ijvs.2021.128983.1615, (A)Athors, 2022, College of Veterinary Medicine, University of Mosul.

This is an open access article under the CC BY 4.0 license (http://creativecommons.org/licenses/by/4.0/).

\section{Introduction}

Newcastle disease (ND) is a major important viral disease of domestic and wild birds caused by para-myxo virus (1). It is characterized by variations in morbidity, mortality, symptoms and lesions (2). The disease is transmitted by direct contact with infected bird secretions (Feces and mouth secretions) (3). There are many strains of virus, lentogenic, mesogenic, and vellogenic strains (4). Three forms of Newcastle disease are recognized: the pneumotropic, viscerotropic and neurotropic forms (3).
Prevention and control of the disease is depending on vaccination and biosecurity. Alive attenuated vaccine against ND could be given by, spray oral and eye drop route. While killed vaccine can be used as a booster dose (5). Immunostimulants play an important role in enhancement the immune system of chickens and improve poultry production. Several types of stimulants with different mechanisms and functions. Complex carbohydrates Apsa $\operatorname{Mos}^{\circledR}$ is a wall extract with a high content (6). 


\section{Material and methods}

Forty broiler chicks (Ross 308) at one-day old of age were reared in the animal house at the college of veteriary medicine, University of Mosul. All environmental requirements of temperature and humidity needed were available for birds in their entire 30 days' period of the experiment. Feed and water was available for ad libitum. Chicks were randomly distributed at a rate of 10birds/treatment. Chicks in the $1^{\text {st }}$ treatment were considered as control one (G1); Chicks in the 2nd treatment were vaccinated with live attenuated vaccine ( $\beta 1$ and Lasota strains), at 10 and 24 days old respectively (G2); Chicks in the 3rd treatment (G3), were vaccinated with live attenuated vaccines (as in G2), and amended with Apsa-mos ${ }^{\circledR}$ at a rate of $1 \mathrm{mg} / \mathrm{kg}$ of feed; Chicks in the 4th treatment were given Apsa-mos ${ }^{\circledR}$ only at a rate of $1 \mathrm{mg} / \mathrm{kg}$ of feed. At the end of the experiment (30 days), blood samples were collected from jugular vein and divided into two parts, the first one was gathered in gel tubes for serum collection, while the other part was gathered in anti-coagulant tubes. Serum samples were collected by lifting gel tubes at room temperature for 2 to 3 hours, then were freeze until estimation of Newcastle antibody titers by using ELISA technique with Biochek ELISA kit (Biochek company). The second part of blood was used for estimating differential leucocytes count.

\section{Histological sections}

At the end of the experiment, five chickens were necropsied and both bursa of fabricious and cecal tonsils were collected in neutral buffered formalin $10 \%$ for histopathological changes by making $5 \mu$ thickness specimens

\section{Statistical analysis}

Statistical analyses of antibody titer levels in different bird groups and differential leucocytes count, were statistically analyzed using one-way ANOVA test. The differences between groups were estimated by using Duncan test with the significances were calculated at a level of $\mathrm{P}<0.05$.

\section{Results}

The effects of NDV vaccine and Apsa- mos ${ }^{\circledR}$ on mean ELISA antibody titers in vaccinated birds at 30 days of age are illustrated in (Table 1). From table it is clear that $\mathrm{s} / \mathrm{p}$ in broilers of groups 1 and 4 had values less than 0.349 , with ELISA mean titers of $20.629 \pm 3.3$ and $71.139 \pm 12$ respectively, representing a negative detection of antibodies, since the titer range was less than 1158 . Values of $\mathrm{s} / \mathrm{p}$ in broiler chickens of group 2 and 3, in which chicks were vaccinated with NDV vaccines at 10 and 24 days of age were greater than 0.350, with ELISA mean titers of $2670 \pm 330.2$ and 3677.70 respectively. No significant differences were recorded in ELISA mean titers of broilers in group 1 and 4, in which birds were not vaccinated with NDV vaccine with G4 or without G1 amending with Apsa- mos ${ }^{\circledR}$. Significant increase in ELISA titers were recorded in boilers of group 2 in comparison with those titers recorded in broilers of group 1 and 4, but even higher significant increase was noticed after Apsa- mos ${ }^{\circledR}$ was added to the feed of birds in group 3, in comparison to all three groups 1,2 and 4 ELISA titers. There was a moderate variation in the titers of both G2 and G3 with a coefficient of variance of 39.120 and 41.610 respectively compared to more variable titers in groups 1 and 4, which were 50.61 and 50.61 respectively. The effects of NDV vaccine and Apsa- mos $^{\circledR}$ on the differential leucocytes count in broiler chickens measured at 30 days of age (Table 2). Almost normal percentages were recorded in all treated groups G1, G2 and G3, when compared with control one, since there were no significant differences between all groups. No stressful adverse effects were recorded through the calculation of the $\mathrm{H} / \mathrm{L}$ ratio $1 \mathrm{n}$ all four group.

Table 1: Effect of Apsa-mos ${ }^{\circledR}$ on mean ELISA titers at 30 days of age

\begin{tabular}{ccccc}
\hline Group & G1 & G2 & G3 & G4 \\
\hline s/p value & less than 0.349 & greater than 0.350 & greater than 0.350 & less than 0.349 \\
titer range & less than 1158 & greater than 1159 & greater than 1159 & less than 1158 \\
antibody status & no antibody detected & Positive & Positive & no antibody detected \\
mean \pm se & $20.629 \pm 3.3 \mathrm{a}$ & $2670 \pm 330.2 \mathrm{~b}$ & $3677.70 \pm 416.6 \mathrm{c}$ & $71.139 \pm 12.1 \mathrm{a}$ \\
CV\% & 50.61 & 39.120 & 41.610 & 50.61 \\
\hline
\end{tabular}

a-c Means followed by different letters are significant at $\mathrm{P}<0.05$.

Table 2: Effect of Apsa-mos ${ }^{\circledR}$ on percentage of leucocytes and $\mathrm{H} / \mathrm{L}$ ratio at 30 days of age

\begin{tabular}{lcccc}
\hline Group & G1 & G2 & G3 & G4 \\
\hline Heterophiles & $28.8 \pm 1.1$ & $27.3 \pm 1.6$ & $27.2 \pm 2.3$ & $29.9 \pm 2.1$ \\
Lymphocytes & $62.8 \pm 1.2$ & $63.3 \pm 1.5$ & $60.3 \pm 2.3$ & $63.2 \pm 1.4$ \\
Monocytes & $6.1 \pm 1.0$ & $13.8 \pm 0.8$ & $11.3 \pm 0.9$ & $3.9 \pm 1.6$ \\
H/L ratio & 0.45 & 0.42 & 0.45 & 0.46 \\
\hline
\end{tabular}


In comparison to the normal architectural of bursal tissue (Figure 1), there is thickening in septum between follicle, necrosis and depletion of lymphocytes in the center of follicle and hyperplasia of epithelium cyst formation due to depletions of lymphocytes (Figure 2) in group 3, the same changes which are seen in group two are seen in group three but in less density. While group 4 appeared significant increase in the density of lymphocyte (Figure 3) in compared with control group. The results of histopathology of cecal tonsil in group two, there is presence of necrosis and depletion of lymphocytes. The same changes were seen in group 3 in less density. In group 4 there is significant increase in lymphocytes (Figure 4).

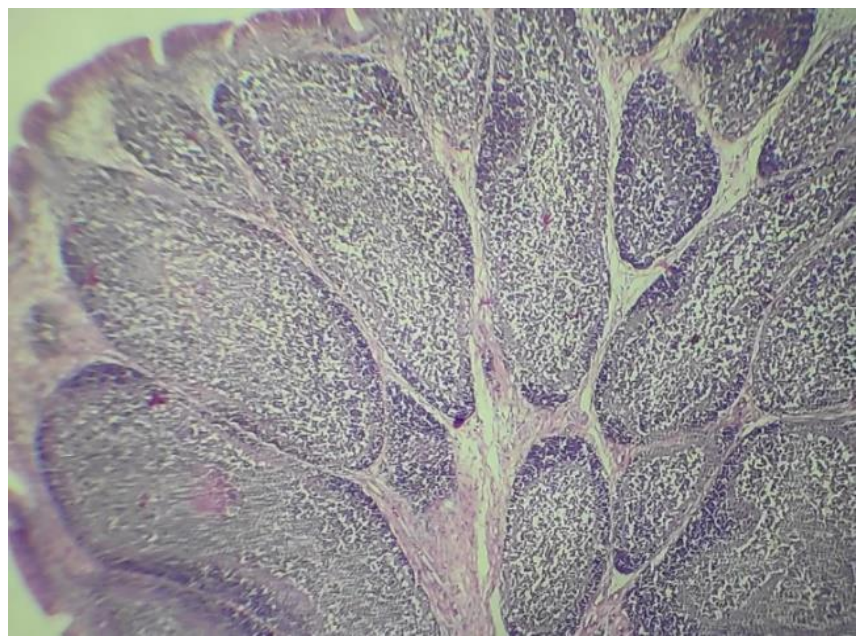

Figure 1: Normal architectural of bursal tissue (control croup). H\&E. 576x.

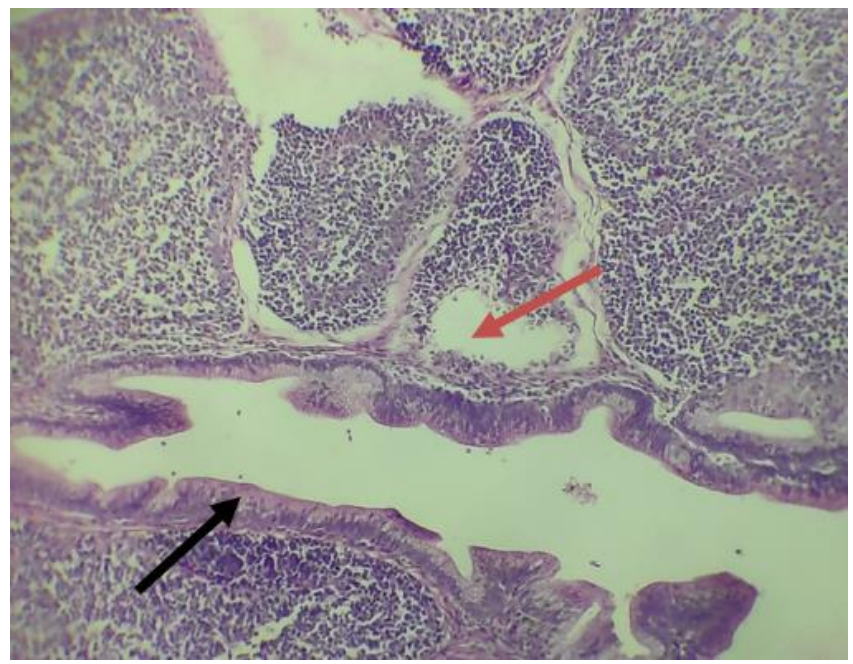

Figure 2: Bursa of fabricious cross section of broiler chicken from G2 at 30-day old showing depletion of lymphocytes in the follicles and cyst formation (red arrow), hyperplasia of epithelium (Black arrow). H\&E. 448x.

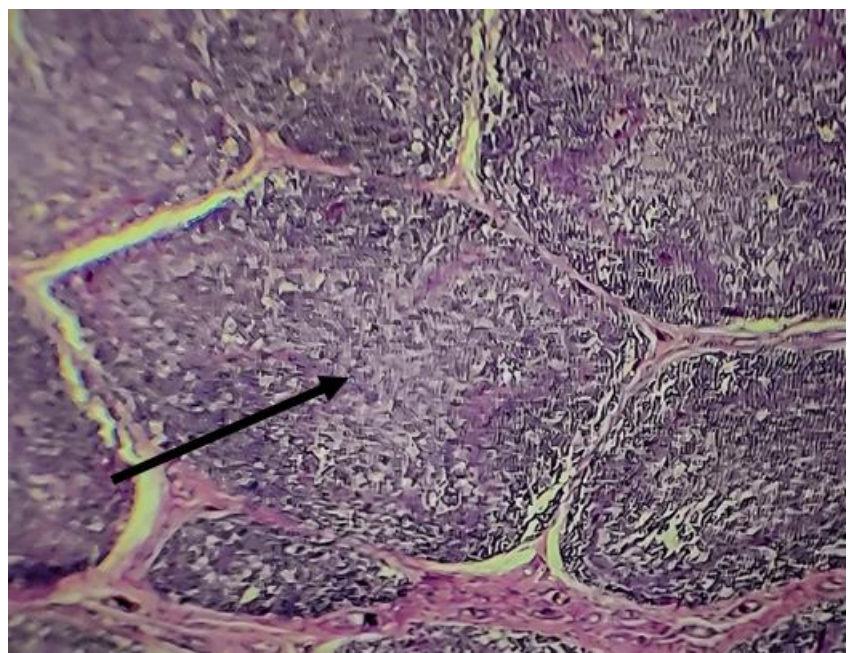

Figure 3: Bursa of fabricia cross section of broiler chicken from G4 at30day old showing increase in the density of lymphocytes inside follicles (arrow). 377x.

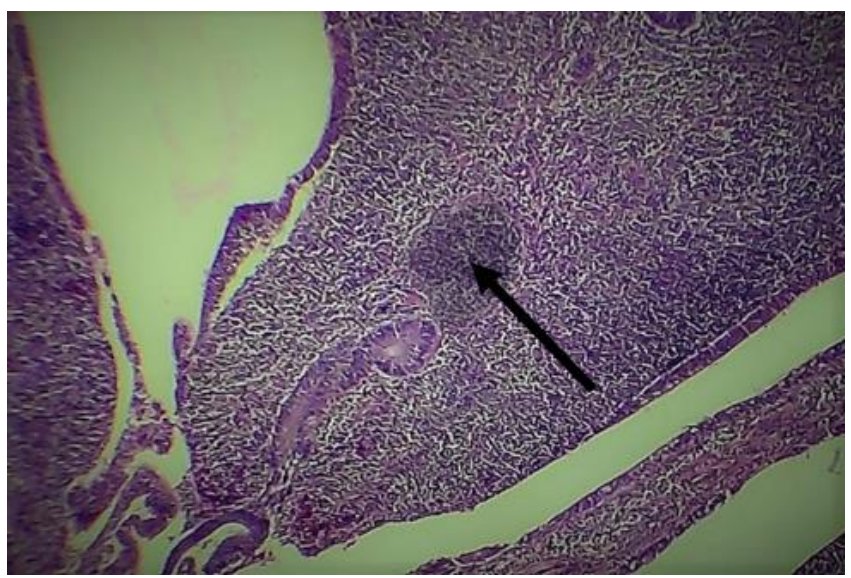

Figure 4: Cross section in cecal tonsils of broiler chicken from group 4 at 30-day old showing increase in the density of lymphocytes (arrow). H\&E. 320X.

\section{Discussion}

In this experiment Apsa-mos ${ }^{\circledR}$ acts as an immune modulatory (6) by enhancing the production of more antibodies against NDV vaccine in chicks of group 3 compared to the titers in broilers of group 2 which received the vaccine only. The titers of the vaccinated birds with or without addition of Apsa -mos ${ }^{\circledR}$ were significantly differed from other groups, and occur within the expect range of mean ELISA titers in broilers 1000-4000, when birds vaccinated with live NDV vaccine (Biochek). This finding went in the same way with Parvin et al. (7) and Kumar (8). The non-detectable antibodies in non-vaccinated groups were due to the waning of maternal antibodies at 4 weeks of age (9). No adverse effect was noted when birds were 
vaccinated with NDV vaccine or with the addition of immunostimulants on the differential granulocytes count which were reflected by the stress factor of the treated birds and these finding were in agreement with Roholla et al. (10). Apsa-mos ${ }^{\circledR}$ addition to the ration of vaccinated and nonvaccinated chickens had its positive effect on the lymphatic tissues of bursa of Fabricious and caecal tonsils reflects its immunostimulant role in restoring the normal architectural shape and details of these lymphoid tissues $(11,12)$.

\section{Conclusion}

We concluded that the giving of Apsa-mos ${ }^{\circledR}$ improve the immune state of the chicks in both types humeral and cellular immunity especially in G3 and decreased the influence of the vaccine in this group and increase the immunity in G4 also Apsa-mos decrease the effect of the vaccine in G3 seen in histological changes in bursa of fabricious and cecal tonsils.

\section{Acknowledgment}

The Authors are very grateful to the College of Veterinary Medicine, University of Mosul for their provided facilities, which helped to improve the quality of this work.

\section{Conflict of interest}

No conflict.

\section{References}

1. Sharif A, Ahmed T, Umer M, Rehman A, Hussain Z. Prevention and control of Newcastle Disease. Inter J Agri innovat Res. 2015;3(2):454. [available ta]

2. Ivan D. Newcastle disease. $5^{\text {th }}$ ed. New York: CRC press; 2019. 255$257 \mathrm{p}$.

3. Alexander DJ, Senne DA. Newcastle disease. $12^{\text {th }}$ ed. New York: CRC press; 2000. 130-176 p.

4. Brown C, Torres A. Foreign animal disease. $7^{\text {th }}$ ed. USA: US Animal Health Association Boca Publications Group; 2008.

5. Amir S, Tanveer A, Muhammad U, Abdul R, Zahid H. Prevention and control of Newcastle disease. Inter J Agr innovat Res. 2014;3(2):23191473. [available at]

6. Mohamed S, Abdel Hafez Moemen A, Mohamed R. Evaluation of some immunostimulants on the immune response of broiler chickens against Avian influenza and Newcastle Diseases Vaccination. Zag Vet J. 2016;44(3):273-281. DOI: 10.21608/zvjz.2016.7881

7. Parvin MA, Rahman MM, Akter MR, Rumi NA, Hossain MK, Rahman MS. Detection of Newcastle Disease virus by rapid NDN. Antigen test kit and antibody titer Level in pre and post vaccination. Inter J Bio Res. 2015;2(4):1-12. [available at]

8. Kumar k, immune stimulatory effect of some feed supplement on laying chicken immunized with lasota vaccine for Newcastle disease. international J Adv Res 2018; 6(8): 1086 - 1093. DOI: 10.21474/IJAR01/7617

9. Timms L, Alexander DJ. Cell Mediated immune response of chickens of Newcastle disease vaccines. Avi Pathol. 1977;6(1):51-90. DOI: 10.1080/03079457708418212

10. Roholla hzadeh H, Nilli, H, Asasi K, Mokhayeri S, Najjari A. H, Respiratory and $\mathrm{G}$. $\mathrm{T}$ tract immune responses of broiler chickens following experimental infector with Newcastle disease virus.; Com cli path. 2018; 27 (5): 1241 - 1255. DOI: 10.1007/s00580-018-2728-Z

11. Cattoli G, Sust L, Terregino C, Brown C. Newcastle disease: A review of field recognition and current methods of laboratory detection. J Vet Dia Investigat. 2011;23(4):637-656. DOI: 10.1177/1040638711407887

12. Khalifeh MS, Amawi MM, Abu-Bssha EA, Bani YI. Assessment of humeral and cellular -mediated immune response in chickens treated with timicosin florfenicol or enrofloxacine at the time of Newcastle disease vaccination. Poul Sci. 2009;88:2118-2124. DOI: 10.3382/ps$\underline{2009-00215}$

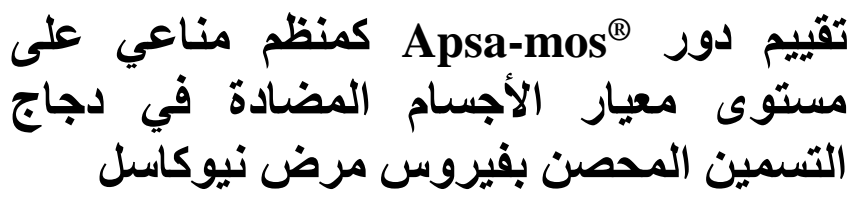

$$
\text { ذانون يونس الحبيطي وزهراء عادل النعيمي الأمراض وأمر اض الدواجن، كلية الطب البيطري، جامعة }
$$

الهدف من دراستتا هو تقييم تأثثر ابساموس كمنبه مناعي على

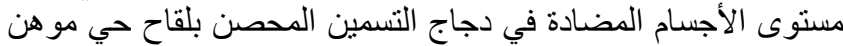

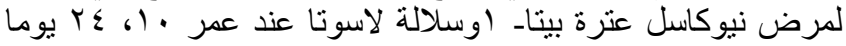

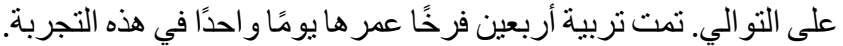

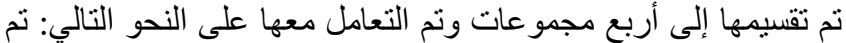
معاملة الكتاكيت في المجموعة الأولى على أنها مجموعة المعة السيطرة

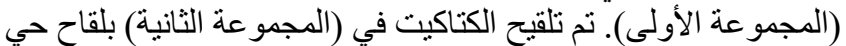

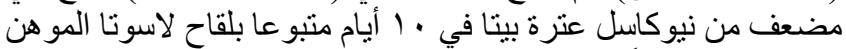

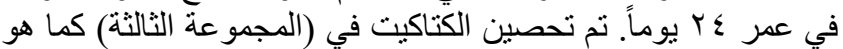

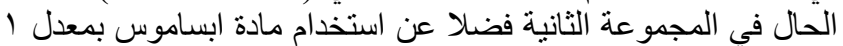
مجم / كجم من العلف، أعطيت الكتاكيت في (المجموعة الرعة الرابعة) ابساموس فقط بمعدل / مجم / كجم من العلف. نم تقدير عيار ات الأجسام المضادة بعد إعطاء لقاحات نيوكاسل باستخدام تقنية الإنزيم المناعي

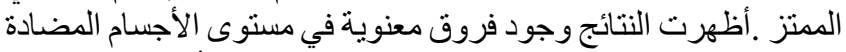

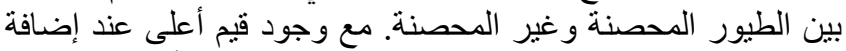
ابساموس إلى المجموعة الثالثة مقارنة بالمجمو عتين الأولى ولى والرئ الرابعة.

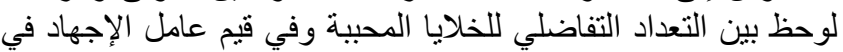

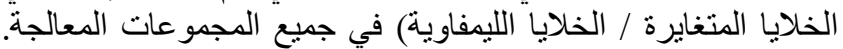

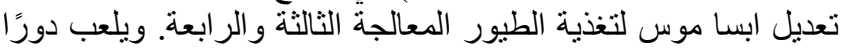

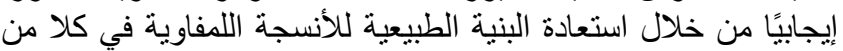

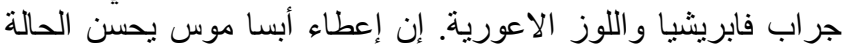

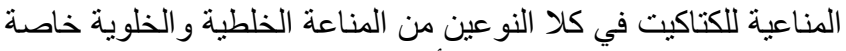

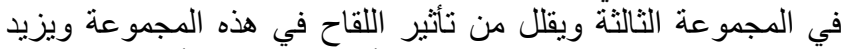

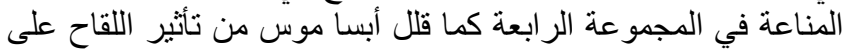
التغيرات النسيجية في جراب فابريشيا واللوز الاعية كورية في المجموعة 